\title{
Ex Cathedra Iuris
}

\section{Peter Goodrich}

Published online: 23 January 2015

(C) Springer Science+Business Media Dordrecht 2015

\section{On Penny Pether}

There is a trait of strength, of fierceness even, that often seems to mark the antipodean. Such, at least, was the case with Penny - that is, Penelope Jane-Pether. She had an unflinching if sometimes bemused eye, strong views, great generosity, and political commitment. She joined the Board of Law and Critique early on and both contributed and pushed radical legal analyses of all sorts to the Board.

Strength is also the ability to express vulnerability. I had not heard from Penny for a long time when I got a call out of the blue. "Peter, I have got cancer ... but I am going to beat the bloody thing". That was the first of many long and painful conversations. She died on the evening of Wednesday September 10, 2013. A good while later than the doctors predicted and all the same ridiculously soon. What I want to say, in introduction and support of her demise, is that all who have lived and lived well, who have lived even half as well as Penny, have beaten death.

She didn't want to die, she said it was too soon, that she wasn't ready and she persisted, in what I viewed as an Australian fashion of the femme forte, living her life to the very end. She did not allow death to compromise or diminish her commitments or beliefs. She continued her classes in the local prisons, she reviewed the work of scholars that she admired, whose support she thought they merited, she flew to Paris for "some decent food" only a few weeks before the end, and equally found time to fall out with her mother, to see friends, to correspond, encourage, hope and then, ineluctably, without remorse, in the wake of intolerable pain, to let go, to die.

Trained in English literature as well as law, Penny was a force for interdisciplinary conjunctions, for the embrace of theory and practice, scholarship and the

P. Goodrich (ه)

Cardozo School of Law, New York, NY 10003, USA

e-mail: goodrich@yu.edu 
profession. She was a believer in rhetoric and critique, in the politics of the literary and yet also a fervent practitioner of the art of change, in the necessity of praxis even or perhaps especially for the cenobitic scholar. That was consistently her role on Law and Critique, her passion in the symposia and special issues in which she participated, in her teaching in the classroom and latterly often in prisons. She left an extraordinary mark that I witnessed constantly, not least by occupying the office she had vacated at Cardozo School of Law. For several semesters subsequent to her leaving that office for a position at American University in Washington, students would drop by looking for Professor Pether. I would engage them, if only to apologize for not being either Penny or Pether, either valuable or strong, and they would invariantly and enthusiastically inform me of how her courses had changed their lives. I understood most of them to mean that she had drawn them through law and literature into an unexpected and excitingly novel understanding of what was possible in thinking law. She had opened new domains; she had energized lagging legal youths, hazed and depressed law students, into realms of praxis and expanded possibilities. With warmth and humour Penny had democratized her small radius of the law school, she had removed their crutches and watched them walk.

It is ironic that Villanova Law School, her last academic home, has dedicated, and blessed, I was there when a priest performed the ceremony, a bench in her name and honour. Scant justice in such an austere and inappropriate rite, but the bench works I think as a small symbol, a token which in the old language serves as a synecdoche, a small part of a much greater and more luminous whole. Her moral force, her political conviction, her commitment to praxis gave her, more than most of us, more than any of us, the moral right to speak ex cathedra, with the legitimacy and candor of critique that had been earned through engagement and lived in exposure to often hostile institutional contexts, their complacencies and bureaucracies. Her bench is empty now, she is ex cathedra in a sadder sense but her specter is undiminished, save that, to borrow a phrase, time can no longer weary her, nor the years condemn. 